\title{
Perancangan Sistem Pengatur Electrical Conductivity (EC) Air Menggunakan Kendali Logika Fuzzy
}

\author{
Ahmad Rifai ${ }^{1}$, Sarmayanta Sembiring ${ }^{2}$, Al Farissi ${ }^{3}$, Donny Giovanna Karo Karo ${ }^{4}$ \\ Sistem Informasi ${ }^{1}$, Sistem Komputer ${ }^{2,4}$, Teknik Informatika ${ }^{3}$ \\ Universitas Sriwijaya \\ Jl. Raya Palembang - Prabumulih Km 32 Indralaya Ogan Ilir \\ Rifai.bae@gmail.com ${ }^{1}$, yanta@unsri.ac.id² ${ }^{2}$ alfarissi.ilkom.@gmail.com ${ }^{3}$, Donnygiokarokaro@gmail.com ${ }^{4}$
}

\begin{abstract}
Abstrak. Telah dirancang sebuah sistem pengatur Electrical Conductivity (EC) air dengan menggunakan kendali logika fuzzy. Sistem pengatur ini berfungsi untuk memutuskan banyaknya volume air dengan EC rendah/tinggi yang harus ditambahkan untuk mencapai EC air pada penampungan sesuai dengan target yang di inputkan. Penambahan air dengan EC rendah/tinggi dilakukan dengan mengalirkannya menggunakan pompa DC dan diditeksi menggunakan water flow sensor dengan penutup aliran menggunakan selonoid valve untuk memastikan volume air yang dialirkan telah sesuai dengan hasil sistem pengatur. Input sistem ini terdiri dari nilai EC air penambah (air dengan EC rendah dan air dengan EC tinggi), target EC air pada penampungan yang diinputkan dengan keypad 4x4, nilai EC air pada penampungan yang diditeksi sensor Konduktivitas, dan volume air pada penampungan yang diditeksi dengan menggunakan sensor ultrasonik. Hasil pengujian menunjukkan sistem telah dapat berjalan dengan baik, dimana sistem dapat menditeksi volume air dengan menggunakan sensor ultrasonik dengan error rata-rata penditeksian jarak sebesar 1,92\%, penditeksi EC dengan menggunakan sensor Konduktivitas telah dapat menditeksi EC dengan error rata-rata sebesar $1,91 \%$, sistem pengatur volume penambah telah berfungsi dengan baik dengan error rata-rata sebesar $1,87 \%$ dan kendali logika fuzzy telah dapat mengambil keputusan banyaknya volume penambah yang harus diberikan untuk mencapai EC target pada penampungan dengan error rata-rata terhadap pengukuran EC setelah hasil pencampuran sebesar $4,17 \%$.
\end{abstract}

Kata Kunci: Kendali logika fuzzy, electrical conductivity (EC), water flow sensor, solenoid valve dan sensor Konduktivitas

\section{Pendahuluan}

Bercocok tanam selain sebagai salah satu usaha juga menjadi hoby bagi sebagian orang. Selain menyalurkan hoby bercocok tanam jenis sayuran dapat memberikan hasil berupa sayuran yang dapat dikonsumsi dan memiliki nilai ekonomis. Keterbatasan lahan didaerah perkotaan menjadi hambatan dalam bercocok tanam secara konvensional. Bercocok tanam dengan metode hidroponik memiliki keunggulan secara kualitas dan kuantitas produksi lebih baik, hasil lebih bersih, efesiensi air dan pupuk, penanggulangan hama lebih mudah dan penggunaan lahan menjadi lebih efesien [1]. Penggunaan lahan yang lebih efesien menjadikan model bercocok tanam hidroponik mulai banyak digemari terutama pada daerah perkotaan.

Hidroponik merupakan suatu metode bercocok tanam selain menggunakan media tanah, hal ini dapat dilakukan karena fungsi tanah sebagai pendukung akar tanaman dan perantara nutrisi dapat diganti dengan cara mengalirkan atau menambah nutrisi,air dan oksigen melalui media seperti batu apung, kerikil, pasir, sabut kelapa, potongan kayu atau busa [2]. Kunci utama dalam pemberian nutrisi pada tanaman pada sistem hidroponik terletak pada pengontrolan EC menggunakan alat Electrical Conductivity (EC) meter. EC digunakan untuk mengetahui cocok tidaknya nutrisi untuk tanaman, keberhasilan produksi sangat ditentukan kualitas nutrisi sementara kualitas nutrisi bergantung pada konsentrasinya [3]. Tingginya EC menunjukkan tingginya kadar garam yang terdapat dalam larutan nutrisi. Tingginya konsentrasi garam dapat merusak akar tanaman serta mengganggu serapan air dan nutrisi oleh akar tanaman [4]. Kebutuhan larutan EC berbeda-beda untuk setiap jenis dan umur tanaman, kebutuhan EC disesuaikan dengan fase pertumbuhan. Ketika tanaman masih kecil maka EC yang dibutuhkan juga kecil, kebutuhan EC akan semakin besar seiring meningkatnya umur tanaman [5].

Pengetahuan dan keterampilan dalam membangun dan memelihara peralatan hidroponik menjadi tantangan tersendiri dalam bercocok tanam hidroponik. Berdasarkan kebutuhan tingkat EC dalam tanaman hidroponik yang berbeda-beda, maka penulis tertarik melakukan penelitian terkait otomatisasi pengaturan EC berdasarkan target (nilai EC yang diinginkan) dengan menggunakan kendali logika fuzzy dengan judul "Perancangan sistem pengatur Electrical Conductivity (EC) air menggunakan kendali logika fuzzy". 
Dalam penelitian I. Puspasari dkk merancang sebuah sistem yang dapat mengendalikan temperatur dan kelembaban serta mengatur konduktivitas dan $\mathrm{pH}$ larutan nutrisi hidroponik model wick pada pembibitan tanaman tomat. Kendali temperatur menggunakan kendali PID sedangkan kendali kelembaban, konduktivitas dan $\mathrm{pH}$ larutan menggunakan kendali on/off [6]. Dalam penelitian Nugraha dkk yang merancang sistem otomatis pengendalian nutrisi untuk tanaman hidroponik dengan mengatur tinggi permukaan air, suhu, tingkat keasaman dan konduktivitas larutan nutrisi pada bak penampungan dengan sistem pakar metode forward chaining. Output dari sistem pakar ini untuk Nutrisi adalah dengan Sistem akan mengalirkan air murni untuk saat mendeteksi tingkat konduktivitas diatas yang telah ditentukan, dan mengalirkan nutrisi ABMix saat nutrisi pada bak penampungan [7].

Berdasarkan penelitian terdahulu terkait EC, maka penulis mengusulkan pengaturan EC dengan cara menambahkan air dengan EC rendah untuk menurunkan EC dan untuk menaikkan EC dengan menambah air dengan EC tinggi. Pengambilan keputusan untuk menentukan berapa banyak volume air dengan EC rendah/tinggi yang harus ditambahkan, peneliti mengusulkan menggunakan kendali logika fuzzy dengan pertimbangan metode fuzzy memiliki kelebihan untuk mengatasi ketidakpastian data dari sensor dengan menggunakan aturan bahasa [8]. Menurut Sri Kusumadewi dalam S. I. Putri (2014:86) berdasarkan efesiensi komputasi dan baik untuk teknik-teknik linear, teknik optimasi dan sistem adaptif dan menjamin kontuinitas hasil [9], maka inferensi fuzzy pada penelitian ini diusulkan menggunakan Takagi-Sugeno. Untuk memastikan volume air dengan EC rendah/tinggi yang ditambahkan dengan cara mengalirinya dengan pompa DC telah sesuai dengan output sistem kendali, maka di gunakan water flow sensor dan solenoid valve.

\section{Teori Pendukung}

\subsection{Sensor Konduktivitas/ TDS / Kadar Garam}

Sensor konduktivitas/ TDS / Kadar Garam memiliki desain yang kompak, probe sensor menggunakan bahan stik stainless. Output sensor ini dapat langsung dihubungkan ke pin analog arduino atau input analog mikrokontroller tanpa memerlukan rangkaian tambahan.Gambar 1 menunjukkan bentuk fisik sensor konduktivitas / TDS / Kadar Garam.

Sensor ini dapat digunakan untuk mengukur konduktivitas, Total Dissolve Solid (TDS) dan salinitas. Adapun spesifikasi sensor sebagai berikut [10]:

1. Tegangan kerja DC 5 Volt

2. Mendukung arduino dan mikrokontroller lainnya.

3. Koefesien linearitas data konduktivitas sebesar 0.9639

4. Koefesien linearitas data TDS sebesar 0.983

5. Memiliki sifat sensitivitas pada bahan bersifat konduktif.

6. Jarak pengukuran $5,5 \mathrm{~cm}$ dari ujung sensor.

7. Persamaan konduktivitas $\mathrm{y}=0.2142 \mathrm{x}+494.93(\mathrm{x}=$ data ADC, $\mathrm{y}=$ konduktivitas $)$

8. Persamaan TDS $\mathrm{y}=0.3417 \mathrm{x}+281.08(\mathrm{x}=$ data ADC, $\mathrm{y}=$ TDS $)$

Gambar 1. Sensor konduktivitas/ TDS / Kadar Garam

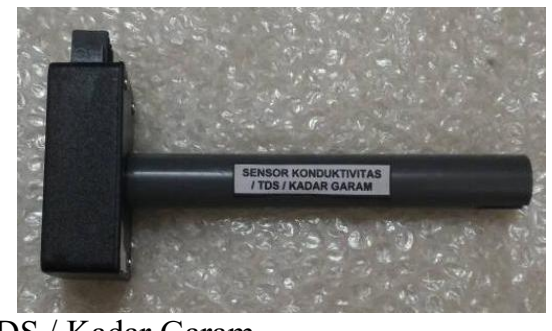




\subsection{Sensor Konduktivitas/ TDS / Kadar Garam}

Prof. Lotfi A. Zadeh dari University of California di Barkeley pada pertengahan tahun 1960, menemukan bahwa logika boolean belum mempertimbangkan keadaan-keadaan yang nyata [11]. Dalam logika fuzzy nilai keanggotaan diantara 0 dan 1 sedangkan logika boolean nilai keanggotaannya bernilai 0 atau bernilai 1 .

Pada tahun 1965 Logika fuzzy modern baru ditemukan, jadi logika fuzzy dapat disebutkan sebagai logika baru yang sudah lama karena sebenarnya sudah sejak lama ada konsep logika fuzzy [12]. Pemikiran tentang pengelolaan dan manajemen ketidakpastian yang dikenalkan oleh Prof. Lotfi A. Zadeh lalu dikenal sebagai logika fuzzy. Gambar 2. menunjukkan konsep dasar logika fuzzy.

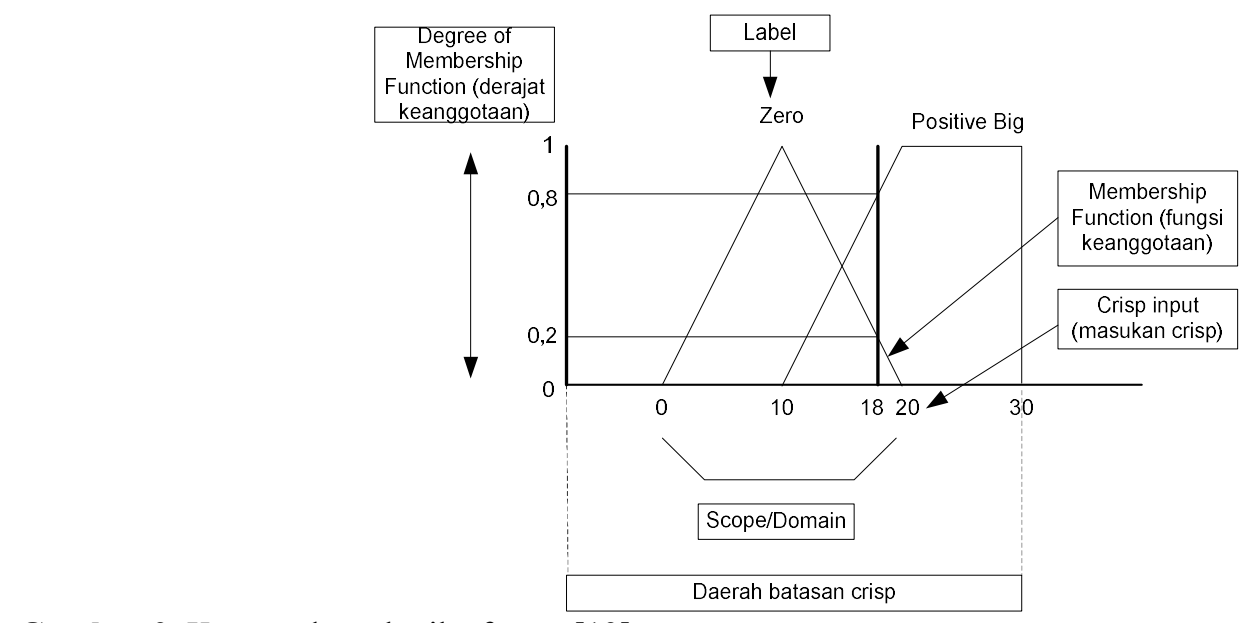

Gambar 2. Konsep dasar logika fuzzy [13].

\section{Perancangan Sistem}

Pada Perancangan sistem pengatur EC menggunakan kendali logika fuzzy, secara umum terbagi menjadi 3 bagian, yaitu Perancangan perangkat keras, perancangan perangkat lunak dan perancangan sistem kendali. Blok diagram sistem keseluruhan ditunjukkan pada Gambar 3.

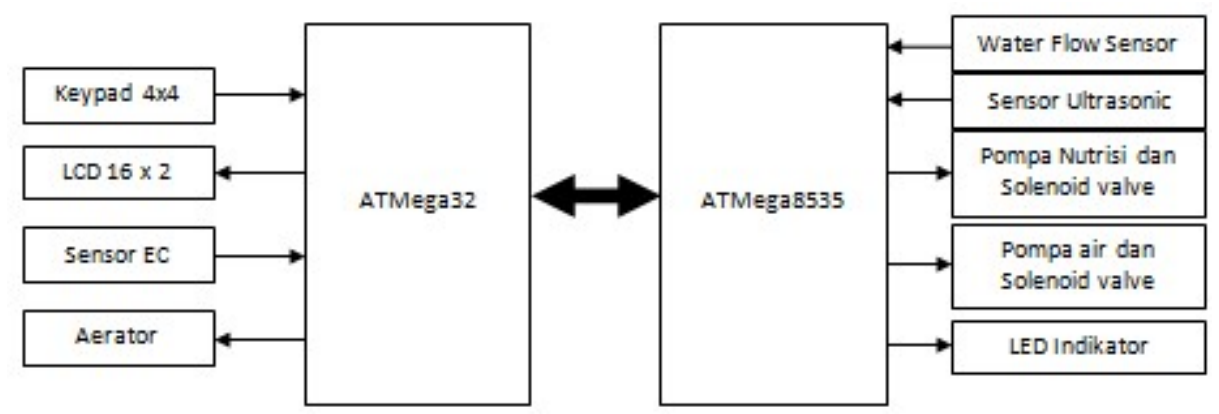

Gambar 3. Blok diagram sistem keseluruhan

Cara kerja sistem ini dengan cara menginputkan EC penambah (air dengan EC rendah dan air dengan EC tinggi), EC Target pada penampungan (EC yang diinginkan), selanjutnya sensor EC akan menditeksi EC pada penampungan dengan menggunakan sensor konduktivitas dan melalukan proses pengambilan keputusan dengan kendali logika fuzzy pada mikrokontroler ATMega32. Selanjutnya output kendali logika fuzzy berupa persentase penambahan air dengan EC rendah/tinggi akan dikirimkan secara serial ke mikrokontroler ATMega8535. Volume air pada penampungan akan dideteksi dengan menggunakan sensor ultrasonik, yang selanjutnya volume air penampungan akan dikalikan dengan output kendali logika fuzzy sebagai informasi banyaknya volume air penambah EC rendah/tinggi yang harus ditambahkan ke penampungan. Penambahan air dengan EC rendah/tinggi dengan volume yang telah ditentukan akan dilaksakan oleh pompa airdengan EC rendah/tinggi, solenoid valve dan water flow sensor. Selama proses berlangsung LED Indikator akan menyala sebagai tanda 
sistem pengendalian EC sedang berlangsung, setelah penambahan air dengan EC rendah/tinggi telah selesai maka dilanjutkan dengan menghidupkan Aerator selama 1 menit untuk membantu proses pencampuran agar cepat merata.

\subsection{Perancangan perangkat keras}

Dalam perancangan sistem ini menggunakan 2 buah mikrokontroler yang saling berkomunikasi secara serial. Mikrokontroler ATMega8535 memiliki input yang berasal dari sensor ultrasonik untuk menditeksi tinggi permukaan air pada penampungan yang selanjutnya akan dikonversi menjadi volume air dalam penampungan. Water flow sensor untuk menghitung banyaknya volume air penambah EC rendah/tinggi yang dialirkan ke penampungan dengan pompa DC dan penutup aliran air penambah menggunakan solenoid valve. Konfigurasi Pin ATMega8535 dengan komponen input/output ditunjukkan pada Table 1. Mikrokontroler ATMega32 memiliki input keypad $4 \times 4$ untuk menerima informasi nilai EC air penambah rendah/tinggi dan target EC pada penampungan. Nilai EC pada penampungan dideteksi dengan menggunakan sensor konduktivitas. Konfigurasi Pin ATMega32 dengan komponen input/output ditunjukkan pada table 2.

Tabel 1. Konfigurasi Pin ATMega8535

\begin{tabular}{ccc}
\hline No & PORT ATMega8535 & KETERANGAN \\
\hline 1 & PINC.2 & Pompa Nutrisi \\
2 & PINC.3 & Pompa Air \\
3 & PINC.4 & LED Indikator \\
4 & PIND.2 & Water Flow \\
5 & PORTD.6 & Echo ultrasonic \\
6 & PORTD.7 & Trigger ultrasonik \\
\hline \multicolumn{4}{c}{} \\
No & Tabel 2. Konfigurasi Pin ATMega32 \\
\hline 1 & PORT ATMega32 & KETERANGAN \\
2 & PINA.3 & Sensor EC \\
3 & PORTC & LCD 16 x 2 \\
4 & PORTB & Keypad 4x4
\end{tabular}

\subsection{Perancangan perangkat Lunak}

Perancangan perangkat lunak pada penelitian ini terdiri dari perancangan sistem input keypad $4 x 4$, penditeksi EC air penampung, menghitung volume air pada penampung, menghitung volume penambah air EC rendah/tinggi dan sistem output volume penambah air dengan EC rendah/tinggi yang di rancang dengan menggunakan Bascom AVR. Secara lengkap flowchart secara keseluruhan ditunjukkan pada Gambar 4. 


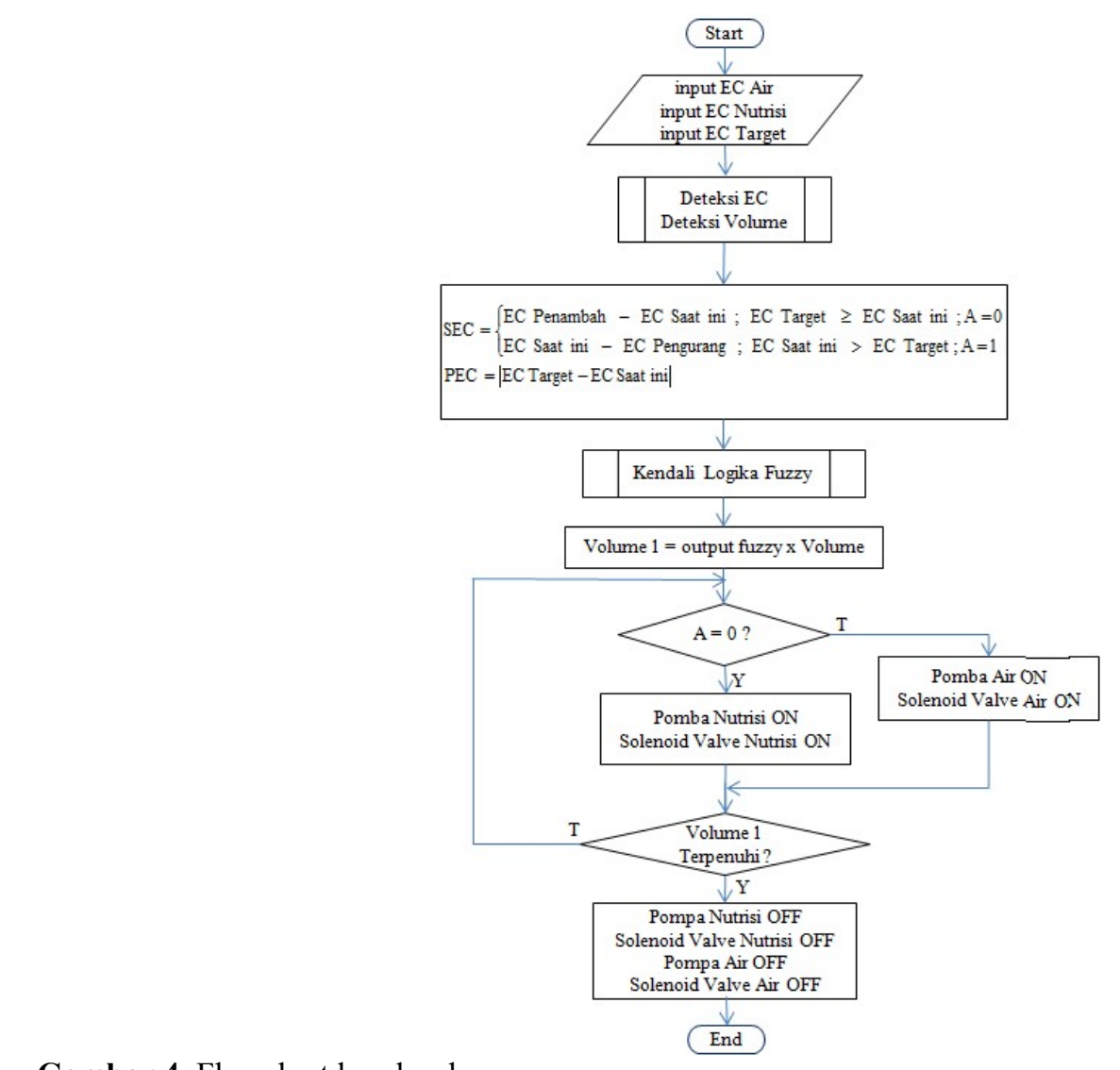

Gambar 4. Flowchart keseluruhan

\subsection{Perancangan sistem kendali}

Sistem kendali EC merupakan sebuah sistem yang dirancang agar dapat membuat EC air pada penampungan sesuai dengan target yang diinginkan. Untuk mencapai EC target dengan cara menambahkan air dengan EC rendah untuk menurunkan EC dan menambahkan air dengan EC tinggi ke penampungan untuk menaikkan EC dengan persentase penambahan volume air dengan EC rendah/tinggi ditentukan sistem kendali saat EC air penampungan tidak sesuai dengan target yang diinginkan. Dalam perancangan sistem kendali EC ini menggunakan sistem kendali logika fuzzy dengan variabel input SEC dan PEC. Nilai SEC (Selisih EC) didapat dari persamaan 1 dan Nilai PEC (Penambahan EC) di dapat dari persamaan 2.

$$
\text { SEC }=\left\{\begin{array}{l}
\text { EC Penambah }- \text { EC Saat ini } ; \text { EC Target } \geq \text { EC Saat ini } \\
\text { EC Saat ini }- \text { EC Pengurang } ; \text { EC Saat ini }>\text { EC Target }
\end{array}\right.
$$

$$
P E C=\mid E C \text { Target }-E C \text { Soot ini } \mid
$$

Dalam perancangan pengendali EC ini memetakan crisp kedalam domain fuzzy menggunakan grafik fungsi keanggotaan dengan representasi grafik fungsi keanggotaan linear turun, segitiga dan bahu. Variabel SEC terdiri dari 4 himpunan fuzzy dan PEC dibagi menjadi 4 himpunan fuzzy yang di desain berdasarkan data hasil pengujian pencampuran air sebanyak $500 \mathrm{~mL}$ dicampur dengan air EC lebih rendah/tinggi dengan selisih 1000 $\mathrm{uS} / \mathrm{cm}, 1500 \mathrm{uS} / \mathrm{cm}$ dan $2000 \mathrm{uS} / \mathrm{cm}$ dengan variasi kombinasi campuran untuk mendapatkan perubahan EC sebesar $50 \mathrm{uS} / \mathrm{cm}, 200 \mathrm{uS} / \mathrm{cm}, 350 \mathrm{uS} / \mathrm{cm}$ dan $500 \mathrm{uS} / \mathrm{cm}$ seperti ditunjukkan pada Tabel 3. 
Tabel 3. Hasil pengujian EC

\begin{tabular}{ccccccc}
\hline \multirow{2}{*}{ No } & \multicolumn{2}{c}{ EC (uS/cm) } & \multicolumn{2}{c}{ Penambahan EC } & \multicolumn{2}{c}{ EC akhir (uS/cm) } \\
& Awal & Penambah & mL & Persen & Total & Selisih \\
\hline 1 & 65 & 1065 & 30 & $6 \%$ & 115 & 50 \\
2 & 65 & 1065 & 115 & $23 \%$ & 265 & 200 \\
3 & 65 & 1065 & 225 & $45 \%$ & 415 & 350 \\
4 & 65 & 1065 & 435 & $87 \%$ & 565 & 500 \\
5 & 146 & 1646 & 20 & $4 \%$ & 196 & 50 \\
6 & 146 & 1646 & 70 & $14 \%$ & 346 & 200 \\
7 & 146 & 1646 & 140 & $28 \%$ & 496 & 350 \\
8 & 146 & 1646 & 215 & $43 \%$ & 646 & 500 \\
9 & 70 & 2070 & 10 & $2 \%$ & 120 & 50 \\
10 & 70 & 2070 & 45 & $9 \%$ & 270 & 200 \\
11 & 70 & 2070 & 85 & $17 \%$ & 420 & 350 \\
12 & 70 & 2070 & 135 & $27 \%$ & 570 & 500 \\
13 & 2215 & 1215 & 30 & $6 \%$ & 2165 & -50 \\
14 & 2215 & 1215 & 115 & $23 \%$ & 2015 & -200 \\
15 & 2215 & 1215 & 225 & $45 \%$ & 1865 & -350 \\
16 & 2215 & 1215 & 435 & $87 \%$ & 1715 & -500 \\
17 & 2218 & 718 & 20 & $4 \%$ & 2168 & -50 \\
18 & 2218 & 718 & 70 & $14 \%$ & 2018 & -200 \\
19 & 2218 & 718 & 140 & $28 \%$ & 1868 & -350 \\
20 & 2218 & 718 & 215 & $43 \%$ & 1718 & -500 \\
21 & 2219 & 219 & 10 & $2 \%$ & 2169 & -50 \\
22 & 2219 & 219 & 45 & $9 \%$ & 2019 & -200 \\
23 & 2219 & 219 & 85 & $17 \%$ & 1869 & -350 \\
24 & 2219 & 219 & 135 & $27 \%$ & 1719 & -500 \\
\hline
\end{tabular}

Berdasarkan Tabel 3 maka dirancang grafik fungsi keanggotaan SEC dan PEC seperti ditunjukkan pada Gambar 5. Tahap selanjutnya masuk ke evaluasi aturan. Banyaknya kombinasi aturan yang memungkinkan terjadi untuk sistem kendali EC menggunakan kendali logika fuzzy dengan dua fungsi keanggotaan, fungsi keanggotaan SEC yang terdiri dari 4 himpunan fuzzy dan fungsi keanggotaan PEC yang terdiri dari 4 fungsi keanggotaan maka secara lengkap kombinasi yang mungkin terdiri atas 16 aturan. Kombinasi aturan secara lengkap dapat dilihat pada Tabel 4.

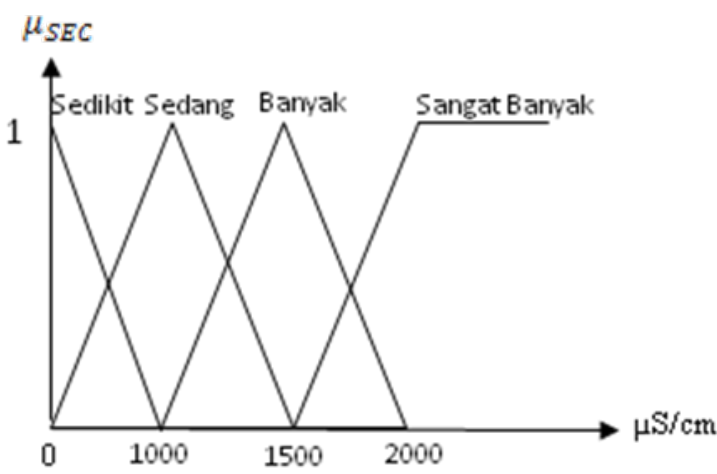

Grafik Fungsi KeanggotaanSEC

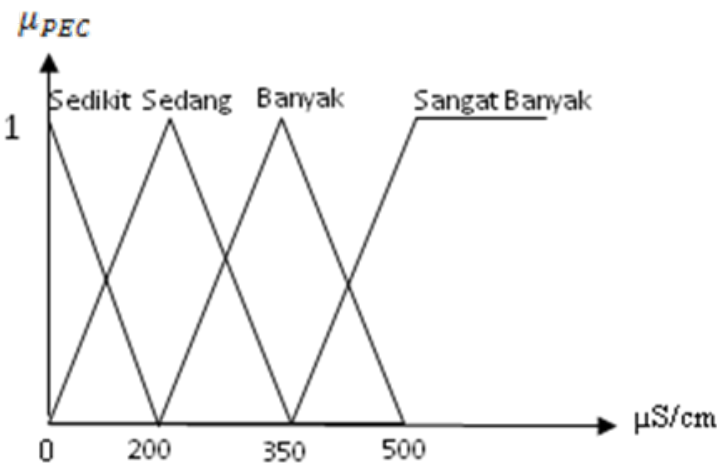

Grafik Fungsi Keanggotaan PEC

Gambar 5. Grafik fungsi keanggotaan SEC dan PEC 
Tabel 4. Rule Base

\begin{tabular}{clll}
\hline No & PP & PT & Output \\
\hline 1 & Sedikit & Sedikit & Sedikit \\
2 & Sedikit & Sedang & Sangat Banyak \\
3 & Sedikit & Banyak & Sangat Banyak \\
4 & Sedang & Sangat Banyak & Sangat Banyak \\
5 & Sedang & Sedikit & Sedikit \\
6 & Sedang & Sedang & Sangat Banyak \\
7 & Sedang & Banyak & Sangat Banyak \\
8 & Sedang & Sangat Banyak & Sangat Banyak \\
9 & Banyak & Sedikit & Sedikit \\
10 & Banyak & Sedang & Banyak \\
11 & Banyak & Banyak & Sangat Banyak \\
12 & Banyak & Sangat Banyak & Sangat Banyak \\
13 & Sangat Banyak & Sedikit & Sedikit \\
14 & Sangat Banyak & Sedang & Sedang \\
15 & Sangat Banyak & Banyak & Banyak \\
16 & Sangat Banyak & Sangat Banyak & Sangat Banyak \\
\hline
\end{tabular}

Tahap akhir dalam perancangan kendali EC dalam penelitian ini adalah pengambilan keputusan berdasarkan rule base yang telah dibuat menggunakan metode Sugeno dalam merancang fuzzy Inferencce. Fungsi implikasi yang digunakan adalah operasi Min-Max terhadap fungsi keanggotaan tertentu untuk menghasilkan fuzzy output berupa nilai sesuai dengan aturan tertentu. Fungsi keanggotaan output PV (Persentase Volume) dibagi menjadi 4 himpunan yang di buat singletone seperti yang ditunjukkan pada Gambar 6.

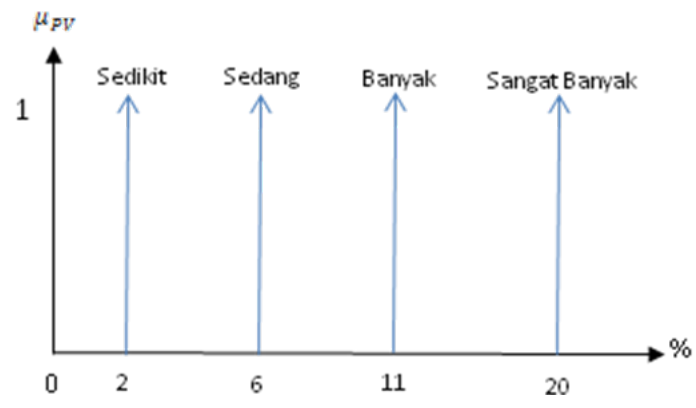

Gambar 6. Grafik fungsi keanggotaan output PV

\section{Hasil dan pembahasan}

Hasil penelitian ini berupa perancangan sistem pengatur EC menggunakan kendali logika fuzzy seperti ditunjukkan pada Gambar 7. Untuk memastikan sistem ini telah berjalan dengan baik, maka dilakukan pengujian sub sistem dan sistem secara keseluruhan. Pengujian meliputi pengujian sensor ultrasonik, pengujian penditeksi EC, pengujian pengatur volume air penambah dan pengujian sistem kendali. Hasil perancangan sistem secara keseluruhan ditunjukkan pada Gambar 7. 


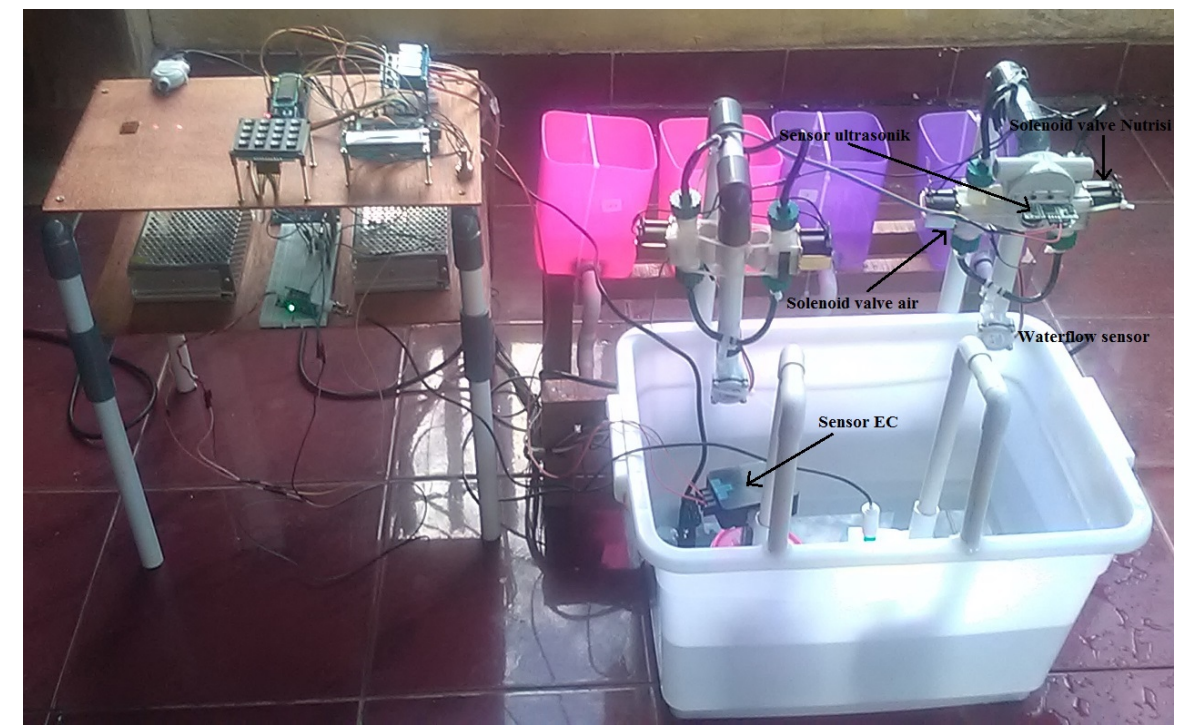

Gambar 7. Hasil perancangan sistem pengatur EC

\subsection{Pengujian sensor ultrasonic}

Sensor ultrasonic digunakan untuk menditeksi jarak sensor terhadap permukaan air di penampungan yang selanjutnya data jarak deteksi tersebut diolah menjadi data banyaknya volume air di dalam penampungan. Tabel 5 menunjukkan hasil pengujian pembacaan sensor ultrasonik.

Tabel 5. Hasil pengujian sensor ultrasonik

\begin{tabular}{cccc}
\hline No & $\begin{array}{c}\text { Jarak Real } \\
(\mathbf{c m})\end{array}$ & $\begin{array}{c}\text { Pembacaan Sensor } \\
(\mathbf{c m})\end{array}$ & $\begin{array}{c}\text { Error } \\
(\mathbf{\%})\end{array}$ \\
\hline 1 & 46,5 & 46,66 & 0,344 \\
2 & 40,5 & 40,78 & 0,691 \\
3 & 37,5 & 37,76 & 0,693 \\
4 & 31,5 & 31,5 & 0 \\
5 & 22,5 & 23,02 & 2,311 \\
6 & 16,5 & 17,12 & 3,757 \\
7 & 13,5 & 14 & 3,703 \\
8 & 7,5 & 7,79 & 3,866 \\
\hline
\end{tabular}

Dari hasil pengujiansensor ultrasonik yang ditunjukkan pada Tabel 5 , terlihat sensor telah dapat bekerja dengan baik dengan error terkecil $0 \%$ pada saat menditeksi jarak 31,15 $\mathrm{cm}$ dan error terbesar 3,866 saat menditeksi jarak 7,5 cm. Rata-rata error pembacaan sensor ultrasonik dalam penelitian ini sebesar $1,92 \%$.

\subsection{Pengujian penditeksi EC}

Pengujian penditeksi EC dilakukan dengan membandingkan output sensor konduktivitas (dalam satuan volt) terhadap pembacaan alat ukur EC (dalam satuan uS/cm) dalam pengukuran variasi sampel EC. Grafik hubungan tegangan hasil output sensor terhadap hasil pembacaan alat ukur EC ditunjukkan pada Gambar 8 berikut ini. 


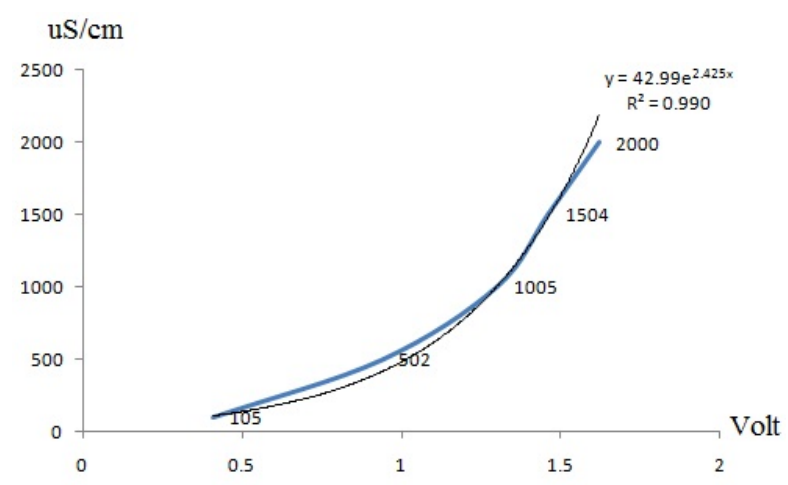

Gambar 8. Grafik pengujian sensor konduktivitas

Dengan menggunakan persamaan 3 untuk mengkonversi tegangan menjadi $\mathrm{uS} / \mathrm{cm}$ dan hasil pengujian sensor konduktivitas ditunjukkan pada Tabel 6.

$$
E C=\left(4 \cdot 10^{-6}\right) \cdot\left(\operatorname{dat}^{2}\right)-(0,016 \cdot \operatorname{dat} a)+18,96
$$

Dengan data $=42,99 . \mathrm{e}^{(2,425 . \mathrm{V})}$ dan V merupakan output sensor konduktivitas.

Tabel 6. Hasil pengujian pembacaan sensor EC

\begin{tabular}{cccc}
\hline No & $\begin{array}{c}\text { Alat ukur } \\
(\mathbf{u S} / \mathbf{c m})\end{array}$ & $\begin{array}{c}\text { Sensor } \\
(\mathbf{u S} / \mathbf{c m})\end{array}$ & $\begin{array}{c}\text { Error } \\
(\mathbf{\%})\end{array}$ \\
\hline 1 & 110 & 109 & $0.91 \%$ \\
2 & 505 & 489 & $3.17 \%$ \\
3 & 1001 & 961 & $4.00 \%$ \\
4 & 1504 & 1483 & $1.40 \%$ \\
5 & 2000 & 1998 & $0.10 \%$ \\
\hline
\end{tabular}

Dari hasil pengujian pembacaan EC menggunakan sensor konduktivitas dengan 5 variasi nilai EC, didapat sensor telah dapat berfungsi dengan baik dengan error rata-rata sebesar1,91\% dengan error terkecil mencapai $0,1 \%$ pada saat pengukuran EC $2000 \mathrm{uS} / \mathrm{cm}$ dan error terbesar 4\% saat mengukur EC $1001 \mathrm{uS} / \mathrm{cm}$.

\subsection{Pengujian pengatur volume}

Air dengan EC rendah dan air dengan EC tinggi dari EC air di penampungan di alirkan dengan menggunakan pompa DC yang terhubung ke selonoid valve dari masing-masing penambah (air dengan EC rendah/tinggi) yang terhubung ke sebuah water flow sensor untuk memastikan air yang dialirkan volumenya telah sesuai dengan yang diperintahkan sistem kendali. Hasil pengujian ditunjukkan pada Tabel 7.

Dari hasil pengujian yang ditunjukkan pada Tabel 7, terlihat sistem pengatur volume air penambah telah berjalan dengan baik, dengan error terkecil untuk penambah air EC rendah mencapai $0 \%$ saat menambahkan air sebanyak $10 \mathrm{~mL}$, error terbesar 5,2\% saat menambahkan air $50 \mathrm{~mL}$ dan error rata-rata untuk menambahkan air $10 \mathrm{~mL}$ s.d. $100 \mathrm{~mL}$ sebesar 4,12\%. Error terkecil untuk penambah air dengan EC tinggi mencapai $0 \%$ saat menambahkan air sebanyak $10 \mathrm{~mL}$ dan $20 \mathrm{~mL}$, error terbesar 3,31\% saat menambahkan air $50 \mathrm{~mL}$ dan error rata-rata untuk menambahkan air $10 \mathrm{~mL}$ s.d. $100 \mathrm{~mL}$ sebesar $1,87 \%$.

Tabel 7. Hasil Pengujian penambahan air dengan EC rendah/tinggi

\begin{tabular}{cccccc}
\hline No & $\begin{array}{c}\text { Volume Real } \\
(\mathbf{m L})\end{array}$ & $\begin{array}{c}\text { EC rendah } \\
(\mathbf{m L})\end{array}$ & $\begin{array}{c}\text { Volume output sistem } \\
\text { Error }\end{array}$ & $\begin{array}{c}\text { EC tinggi } \\
(\mathbf{m L})\end{array}$ & $\begin{array}{c}\text { Error } \\
(\%)\end{array}$ \\
\hline 1 & 10 & 10 & $0.00 \%$ & 10 & $0.00 \%$ \\
2 & 20 & 19 & $5.00 \%$ & 20 & $0.00 \%$ \\
3 & 30 & 28.5 & $5.00 \%$ & 29.2 & $2.74 \%$ \\
\hline
\end{tabular}




\begin{tabular}{cccccc}
\hline 4 & 40 & 38 & $5.00 \%$ & 41 & $2.44 \%$ \\
5 & 50 & 47.4 & $5.20 \%$ & 48.4 & $3.31 \%$ \\
6 & 100 & 95.5 & $4.50 \%$ & 102.8 & $2.72 \%$ \\
\hline
\end{tabular}

\subsection{Pengujian sistem kendali}

Sistem pengatur yang dirancang dengan kendali logika fuzzy ini memiliki output penambahan air dengan EC rendah/tinggi dengan banyaknya volume penambahan di dapat dari volume air dipenampungan dikali dengan output sistem. Untuk memastikan sistem telah berjalan dengan baik, maka dilakukan pengujian dengan cara menginputkan nilai EC air penambah EC rendah/tinggi, nilai EC di penampungan, nilai EC yang di inginkan (EC target) dan volume air dipenampungan. Sistem kendali fuzzy akan memproses data yang diinputkan lalu akan menghasilkan output berupa persentase penambahan yang selanjutnya akan di kali dengan volume awal air (dalam penelitian ini volume awal sebanyak 500mL). Pengujian dilakukan untuk output (mL) yang tidak melebihi $20 \%$ dari volume air di penampungan. Pencampuran air dengan EC rendah/tinggi dilakukan sesuai dengan volume yang dihasilkan sistem dan dilakukan pengukuran EC dari hasil pencampuran dengan menggunakan EC meter (uS/cm), secara lengkap hasil pengujian ditunjukkan pada Tabel 8.

Tabel 8. Hasil pengujian sistem kendali

\begin{tabular}{cccccccc}
\hline No & $\begin{array}{c}\text { EC Saat ini } \\
\text { (uS/cm) }\end{array}$ & $\begin{array}{c}\text { Volume } \\
\text { Awal (mL) }\end{array}$ & $\begin{array}{c}\text { EC Penambah } \\
\text { (uS/cm) }\end{array}$ & $\begin{array}{c}\text { Penambahan } \\
\text { Volume (mL) }\end{array}$ & $\begin{array}{c}\text { EC Target } \\
(\mathbf{u S} / \mathbf{c m})\end{array}$ & $\begin{array}{c}\text { EC Akhir } \\
(\mathbf{u S} / \mathbf{c m})\end{array}$ & $\begin{array}{c}\text { Error } \\
(\%))\end{array}$ \\
\hline 1 & 258 & 500 & 1158 & 64 & 378 & 369 & $2.38 \%$ \\
2 & 228 & 500 & 1628 & 47.5 & 348 & 365 & $4.89 \%$ \\
3 & 228 & 500 & 1628 & 64 & 438 & 433 & $1.14 \%$ \\
4 & 228 & 500 & 1628 & 96.5 & 568 & 534 & $5.99 \%$ \\
5 & 225 & 500 & 2125 & 27.5 & 345 & 360 & $4.35 \%$ \\
6 & 225 & 500 & 2125 & 39 & 435 & 440 & $1.15 \%$ \\
7 & 225 & 500 & 2125 & 61.8 & 565 & 530 & $6.19 \%$ \\
8 & 1200 & 500 & 300 & 64 & 1080 & 1111 & $2.87 \%$ \\
9 & 1628 & 500 & 228 & 47.5 & 1508 & 1558 & $3.32 \%$ \\
10 & 1628 & 500 & 228 & 64 & 1418 & 1535 & $8.25 \%$ \\
11 & 2197 & 500 & 297 & 27.5 & 2077 & 2131 & $2.60 \%$ \\
12 & 2197 & 500 & 297 & 39 & 1987 & 2124 & $6.89 \%$ \\
\hline
\end{tabular}

Dari hasil pengujian didapat sistem kendali dengan logika fuzzy telah berjalan dengan baik, dimana EC target yang diinputkan ke sistem telah mendekati EC Real (Pengukuran dengan alat ukur EC) dengan error rata-rata sebesar 4,17\% dengan error terlecil sebesar 1,14\% pada menaikkan EC dengan EC target $438 \mathrm{uS} / \mathrm{cm}$ dan error terbesar 8,25\% pada saat penurunan nilai EC dengan target $1418 \mathrm{uS} / \mathrm{cm}$.

\section{Kesimpulan}

Dari hasil hasil pengujian dapatlah disimpulkan :

1. Sensor jarak ultrasonic telah dapat bekerja dengan baik dengan error rata-rata $1,92 \%$ dengan error terkecil $0 \%$ dan error terbesar 3,866\%.

2. Penditeksi Electrical Conductivity (EC) dalam satuan uS/cm yang di rancang telah berjalan dengan baik, dengan error rata-rata sebesar $1,91 \%$, error terkecil sebesar $0,1 \%$ dan error terbesar sebesar $4 \%$.

3. Sistem pengatur volume untuk menambahkan air dengan EC rendah/tinggi yang dirancang telah berfungsi dengan baik. Hasil pengujian penambahan dengan volume $10 \mathrm{~mL}$ sampai dengan $100 \mathrm{~mL}$ menunjukkan bahwa sistem pengatur volume dapat mengalirkan penambah air EC rendah/tinggi sesuai dengan yang di inputkan dengan error rata-rata $1,87 \%$.

4. Sistem pengatur EC yang dirancang dengan menggunakan kendali logika fuzzy untuk mengambil keputusan penambahan air dengan EC rendah/tinggi yang harus ditambahkan untuk mencapai EC target telah berfungsi dengan baik. Hasil pengujian menunjukkan bahwa sistem kendali dapat memutuskan banyaknya volume air penambah yang harus diberikan untuk mencapai EC target yang di inputkan dengan error rata-rata terhadap hasil pengukuran setelah pencampuran sebesar 4,17\%. Error terkecil terjadi pada 
saat penambahan EC dengan error 1,14\% dan error terbesar pada saat penurunan EC dengan error sebesar $8,25 \%$.

\section{Ucapan Terima Kasih (Acknowledgement)}

Penulis mengucapkan terima kasih kepada LPPM Universitas Sriwijaya yang telah mendanai penelitian dalam skim SATEKS ini dengan Nomor Kontrak : 0179.30/UN9/SB3.LP2M.PT/2018.

\section{Referensi}

[1] www.antaranews.com, "Hidroponik mulai diminati masyarakat perkotaan," 2016. https://www.antaranews.com/berita/595714/hidroponik-mulai-diminati-masyarakat-perkotaan (accessed Mar. 10, 2018).

[2] I. S. Roidah, "Pemanfaatan lahan dengan menggunakan sistem hidroponik," J. Bonorowo, vol. 1, no. 2, pp. 43-49, 2015.

[3] R. Rosliani and N. Sumarni, "Budidaya tanaman sayuran dengan sistem hidroponik," Bandung Balai Penelit. Tanam. Sayuran, 2005.

[4] A. W. Wibowo, A. Suryanto, and A. Nugroho, "Kajian Pemberian Berbagai Dosis Larutan Nutrisi Dan Media Tanam Secara Hidroponik Sistem Substrat Pada Tanaman Kailan (Brassica Oleracea L.)," $J$. Produksi Tanam., vol. 5, no. 7, pp. 1119-1125, 2017.

[5] "Pengaruh EC dan pH Pada larutan Nutrisi Hidroponik," 2017. www.yoonhidroponik.web.id/2017/05/pengaruh-ec-dan-ph-pada-larutan-nutrisi.html. (accessed Mar. 11, 2018).

[6] I. Puspasari, Y. Triwidyastuti, and H. Harianto, "Otomasi Sistem Hidroponik Wick Terintegrasi pada Pembibitan Tomat Ceri,” J. Nas. Tek. Elektro dan Teknol. Inf., vol. 7, no. 1, pp. 97-104, 2018.

[7] Y. E. Nugraha, B. Irawan, and R. E. Saputra, "Pengembangan Sistem Otomatisasi Pengendalian Nutrisi Pada Hidroponik Menggunakan Sistem Pakar Dengan Metode Forward Chaining," eProceedings Eng., vol. 4, no. 2, 2017.

[8] Q. Bao, S. Li, W. Shang, and M. An, “A fuzzy behavior-based architecture for mobile robot navigation in unknown environments," in 2009 International Conference on Artificial Intelligence and Computational Intelligence, 2009, vol. 2, pp. 257-261.

[9] S. I. Putri, H. Suyono, and R. N. Hasanah, "Rancang Bangun dan Optimasi Panel Surya Berpenjejak dengan Logika Fuzzy Takagi-Sugeno,” J. EECCIS, vol. 8, no. 1, pp. 85-92, 2014.

[10] depoinovasi.com, "Datasheet Sensor konduktivitas / TDS / Kadar Garam." http://depoinovasi.com/downlot.php?file=datasheet sensor konduktivitas_tds_kadar_garam.pdf (accessed Mar. 10, 2018).

[11] Setiadji, Himpunan \& Logika Samar Serta Aplikasinya. Yogyakarta: Graha Ilmu., 2009.

[12] T.Sutojo, E. Mulyanto, and V. Suhartono, Kecerdasan Buatan. Yogyakarta: ANDI, 2011.

[13] Sudradjat, Dasar-Dasar Logika Fuzzy (Modul Kuliah). Bandung: Jurusan Matematika FMIPA Universitas Padjadjaran, 2008. 
